\title{
Population structure and fecundity of Upogebia omissa (Decapoda: Gebiidea: Upogebiidae) in an estuarine region in Sergipe, northeastern Brazil
}

\author{
Rafael de Carvalho Santos ${ }^{1,2}$, Luiz Filipe Santos Silva ${ }^{3}$, Bruna dos Santos ${ }^{3}$, Juliana \\ Menezes Motta ${ }^{3}$ \& Douglas Fernandes Rodrigues Alves ${ }^{1,4}$
}

(1) Universidade Federal de Sergipe, Centro de Ciências Biológicas e da Saúde, Departamento de Biologia, Laboratório de Carcinologia, Rosa Elze, São Cristóvão 49100-000, Sergipe, Brazil. E-mail: rafa_bio@hotmail.com.br

(2) Universidade Estadual Paulista, Faculdade de Ciências de Bauru, Departamento de Ciências Biológicas, Laboratório de Biologia de Camarões Marinhos e de Água Doce (LABCAM), Bauru 81531-980, São Paulo, Brazil.

(3) Universidade Federal de Sergipe, Centro de Ciências Biológicas e da Saúde, Departamento de Biologia, Rosa Elze, São Cristóvão 49100-000, Sergipe, Brazil.

(4) Universidade Estadual Paulista, Instituto de Biociências, Departamento de Zoologia, Group of Studies on Crustacean Biology, Ecology and Culture (NEBECC), Botucatu 18618-000, São Paulo, Brazil. E-mail: douglas_biologo@yahoo.com.br

Santos R.C., Silva L.F.S., Santos B., Motta J.M. \& Alves D.F.R. (2018) Population structure and fecundity of Upogebia omissa (Decapoda: Gebiidea: Upogebiidae) in an estuarine region in Sergipe, northeastern Brazil. Pesquisa e Ensino em Ciências Exatas e da Natureza, 2(2): 95-104.

http://dx.doi.org/10.29215/pecen.v2i2.1064

Academic editor: Mauro de Melo Júnior. Received: 06 April 2018. Accepted: 12 August 2018. Published: 28 December 2018.

Estrutura populacional e fecundidade de Upogebia omissa (Decapoda: Gebiidae: Upogebiidae) em uma região estuarina em Sergipe, nordeste do Brasil

Resumo: Camarões de lama da família Upogebiidae são organismos importantes de comunidades de substrato não consolidado, onde eles cavam tocas agindo como engenheiros ecossistêmicos. $\mathrm{O}$ presente estudo descreve alguns parâmetros da estrutura populacional e biologia reprodutiva do camarão de lama Upogebia omissa. A coleta dos indivíduos foi realizada no estuário do rio Vaza-Barris, estado de Sergipe, nordeste do Brasil. Em laboratório, os espécimes foram sexados e mensurados quanto ao comprimento da carapaça $(\mathrm{CL})$. Fêmeas ovígeras tiveram o total de ovos contados. $\mathrm{O}$ tamanho do corpo variou entre 3,0 e 12,9 mm CL, sendo os machos significativamente menores que as fêmeas. A razão sexual média foi de 0,34, voltado para as fêmeas (teste binomial, $\mathrm{P}=0,001$ ). A fecundidade variou de 240 a 2339 ovos por fêmea, e foi significativamente afetada pelo tamanho do corpo. Dimorfismo sexual evidenciado pelo tamanho médio de cada sexo é um padrão comum em decápodes que incubam ovos, e nesse caso, a fecundidade normalmente varia em função do tamanho do corpo. Por fim, sugerimos que estudos adicionais são necessários, devido à importância ecológica desses camarões de lama e da escassez de estudos sobre eles.

Palavras chave: Fecundidade, dimorfismo sexual, camarão de lama, estuário.

Abstract: Upogebiidae mud shrimps are important organisms in soft-bottom communities, where they dig burrows acting as ecosystem engineers. The present study describes some parameters of the population structure and the reproductive biology of the mud shrimp Upogebia omissa. The mud shrimps were sampled in the Vaza-Barris estuarine river, Sergipe State, northeastern Brazil. In laboratory, specimens were sexed and measured for carapace length (CL). Ovigerous females had their total eggs counted. The body size ranged between 3.0 and $12.9 \mathrm{~mm}$ CL. Males were significantly smaller than females. The overall sex ratio was 0.34 , female-biased (binomial test, $\mathrm{P}=0.001$ ). Fecundity ranged from 240 to 2339 eggs per female, 
and it was significantly affected by the bodysize. The sexual dimorphism evidenced by the mean size of each sex is a common pattern in decapods that incubate eggs, and in that case, fecundity normally varies in function of body size. Finally, we suggest that additional studies are needed, given the ecological importance of these mud shrimps and the scarcity of studies about them.

Key words: Fecundity, sexual dimorphism, mud shrimp, estuary.

\section{Introduction}

Mud shrimps from the infraorder Gebiidea de Saint Laurent, 1979 are important organisms of the soft-bottom marine and estuarine benthic communities (Selin 2014). In softbottom, these shrimps are burrow dwellers (Das et al. 2017). Therefore, mud shrimps are examples of organisms acting as ecosystem engineers (Jones et al. 1994; Dworschak 2000; D'Andrea \& DeWitt 2009; Kinochita et al. 2010). These organisms play an important ecological role through their bioturbation behavior, redistributing the sediment (Anderson \& Kristenser 1991; Wilde 1991; Meadows \& Meadows 1991; Byer \& Grabowski 2014). Among them, the family Upogebiidae Borradaile, 1903 consists of 139 species (Dworschak 2000). Most of them are benthic and burrow-dwelling organisms while a few species are known for dwelling in corals and sponges (Dworschak 1987; Atkinson \& Taylor 1988; Griffis \& Suchanek 1991; Nickell \& Atkinson 1995; Kinoshita \& Itani 2005). Along the Brazilian coast, the family Upogebiidae is represented by two genera, Pomatogebia Williams \& Ngoc-ho, 1990 and Upogebia Leach, 1814, which in turn, are represented by one and nine species, respectively (Melo 1999; Coelho et al. 2007).

The population structure of the mud shrimps of Upogebiidae family commonly presents a sex ratio pattern female biased, in which the females are found in higher abundances and generally with larger body sizes (Dumbauld et al. 1996; Pinn et al. 2001; Yamasaki et al. 2010; Selin 2014). Similar patterns were already found in populations of mud shrimps, such as the found for Upogebia africana (Ortmann, 1894) in southern Africa (Hanekon \& Erasmus 1989; Hanekon \& Baird 1992) and for Upogebia deltaura (Leach, 1816) in the west coast of Sweden (Tunberg 1986). However, some populations may present an inverse pattern, e.g. for Upogebia pusilla (Petagna, 1792), in which males reach larger sizes than females in the coast of Greece (Kevrekidis et al. 1977). For these organisms, population parameters (e.g., sex ratio, abundance and body size) can vary through distinct regions, depending of the environmental parameters, such as water temperature, salinity, sediment type, food availability and also of ecological interactions, such as agonistic interaction and parasitism (Dworschak 1988; Jugovic et al. 2017).

The mud shrimp Upogebia omissa Gomes Corrêa, 1968 is endemic to the Western Atlantic, where it is widely distributed and occurs along the coast of the America, from Florida, USA, to Santa Catarina, Brazil (Melo 1999; Coelho et al. 2007), including tropical and temperate regions. This species occurs from the intertidal zone to about $10 \mathrm{~m}$ depth, in corals and estuaries (Melo 1999). In those environments, U. omissa employs different trophic strategies, and since mud shrimps can be either filter feeders or deposit feeders depending on their lifestyle, they can be considered more of generalist feeders (Coelho et al. 2000). In spite of the ecological importance of $U$. omissa as an ecosystem engineer and a member of different trophic levels, especially in estuarine zones, information concerning the main features of its population biology remains lacking.

Thus, considering the scarcity of information about biologic aspects of this mud shrimp along Brazilian coast, the aim of this study was to analyze some aspects of the population structure and reproductive biology of Upogebia omissa, focusing on their size structure, sex ratio and fecundity in an estuarine area in Sergipe, northeastern Brazil.

\section{Material and Methods}

\section{Study area and sampling methods}


The sampling program was conducted between July and November 2017, in a region

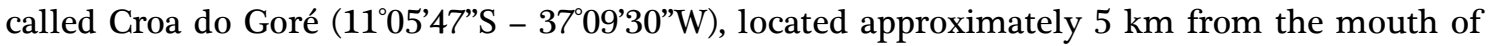
the Vaza-Barris estuary, one of the main estuarine system in Sergipe State, northeastern Brazil (Figure 1A). This estuary extends for approximately $20 \mathrm{~km}$ along the coast and its mangrove forest is composed mainly by specimens of the genera Rizophora, Laguncularia and Avicennia (Carvalho \& Fontes 2007; Hirose et al. 2015). The burrows inhabited by mud shrimps were scattered along the substrate up to the intertidal zone, in a fringe mangrove forest (Figure 1BC), during low tide. Specimens of mud shrimp Upogebia omissa (Figure 1D) were randomly extracted from the burrows with a spatula.

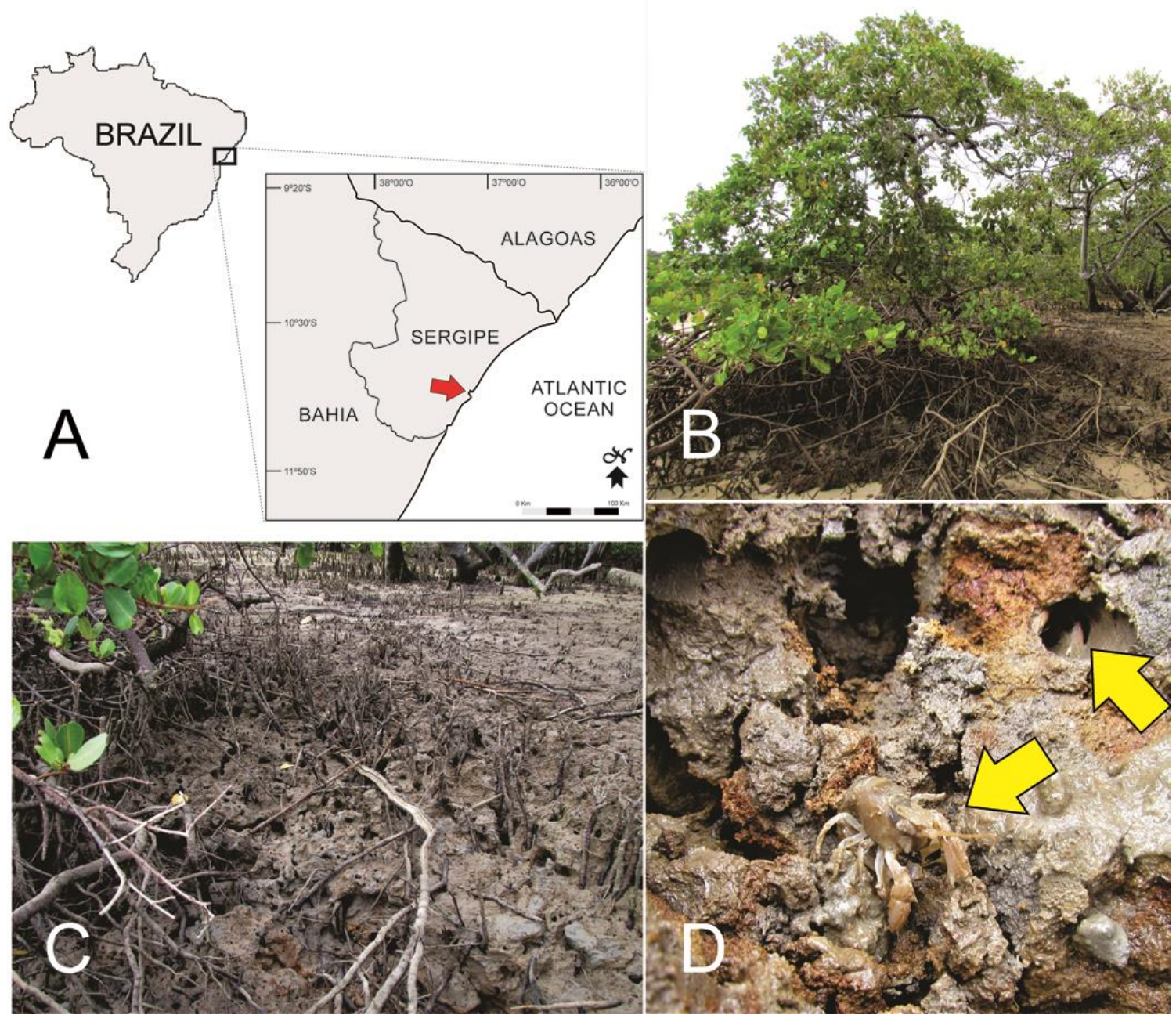

Figure 1. Sampling area: A. Sergipe State, northeastern coast of Brazil, red arrow showing Vaza-Barris estuary region; B-C. Sampling sites and fringe mangrove forest; D. Burrows inhabited by mud shrimps (yellow arrows) distributed on the sediment of the intertidal zone. Photo credits: Douglas F.R. Alves.

In each sampling, a transect of approximately $20 \mathrm{~m}$ was outlined parallel to the fringe mangrove forest. All mud shrimps collected in this transect were placed into individual plastic bags filled with seawater and transported to the laboratory for further analysis. We measured water temperature (T) and salinity $(\mathrm{S})$ on each sampling day. Salinity was measured with a handheld refractometer $($ BIOBRIX, precision $=0.5 \mathrm{PSU}$ ). Temperature was measured with a mercury thermometer (INCOTERM, accuracy $=0.5^{\circ} \mathrm{C}$ ). Mean values of temperature and salinity were $\mathrm{T}=$ $23.0 \pm 1.3^{\circ} \mathrm{C}$, and $\mathrm{S}=39.0 \pm 1.0$, respectively.

Laboratorial procedure 
In laboratory, the identification of the individuals to the species level was based on specific literature (e.g., Melo 1999). Specimens of Upogebia omissa were preserved in properly labeled bottles containing ethanol $70 \%$. The specimens were sexed based on the presence of anterior pleopods in females and the absence of which in males (Dumbauld et al. 2010). Carapace length (CL) was measured via stereomicroscope (Leica M205C) using the imaging software Leica Application Suite (LAS) version 4.4. All ovigerous females were examined via stereomicroscope and all of the embryos they carried underneath their abdomen were carefully detached with forceps and counted. The eggs carried by female shrimps were categorized according to Wehrtmann \& Lardies (1999) into three different groups: Stage I, round egg with uniformly distributed yolk, no visible eye pigments; Stage II, ovoid egg, embryos with elongated eye pigments; and Stage III, ovoid egg, with well-developed eyes and a free pleon.

\section{Data analysis}

Statistical analyses were done after ensuring that all data met the assumptions required (homogeneity of variances and distributions of residuals) (Zar 2010). Sex ratio was estimated as the quotient between the number of males and the total number of individuals. Thus, sex ratios higher or lower than 0.5 should indicate whether the population is skewed toward males or females, respectively. The individuals were distributed into 11 size classes, from 3.0 to $12.9 \mathrm{~mm}$ CL with an interval of $0.9 \mathrm{~mm}$ between them. For each size class, we tested deviations from a 1:1 sex ratio using a binomial test (Wilson \& Hardy 2002). Size comparisons between sexes were performed with the Mann-Whitney test $(\alpha=0.05)$.

The ratio of the body size (CL) and fecundity was calculated. The data was transformed by $\log$, and the relationship between the independent variable (CL) and the dependent variable (fecundity) was analyzed by simple linear regression. Finally, we conducted an analysis of covariance (ANCOVA) to test if fecundity differed between egg stages (eggs with embryo development in stage I, II or III, as independent factor) and shrimp body size (CL, as covariate) (Zar 2010). We conducted multiple comparisons of means (between groups at different egg stages) using the Tukey test (Zar 2010), with $\alpha=0.05$.

\section{Results}

A total of 96 specimens of Upogebia omissa were recorded, being 33 males and 63 females, of which 20 were ovigerous. The overall sex ratio during the study period was 0.34 , with a significant female-biased departure from a 1:1 ratio $(P=0.001)$. Skewed sex ratios were verified for females in the initial and final size classes and did not differ significantly from a 1:1 ratio in the intermediate sizes (Figure 2A). The mean size registered for the specimens was $6.83 \pm 1.79$ $\mathrm{mm}$ CL, ranging from 3.26 to $12.31 \mathrm{~mm}$ CL (Figure 2B). Males (6.60 $\pm 1.83 \mathrm{~mm}$; range 3.26 to $11.70 \mathrm{~mm} \mathrm{CL})$ were significantly smaller compared to females $(7.24 \pm 1.79 \mathrm{~mm}$; range 4.16 to $12.31 \mathrm{~mm} \mathrm{CL}$ ) (Mann-Whitney U Test, $\mathrm{U}=729.000, \mathrm{P}=0.03$ ).

The smallest ovigerous female measured $5.5 \mathrm{~mm}$ CL (Figure 2B). Fecundity varied from 240 to 2339 eggs, with a mean \pm S.D. of $976 \pm 657$ eggs per female. In females carrying early eggs (stage I), fecundity varied from 336 to 2339 , with mean of $1149.30 \pm 649.32$ eggs per female. In turn, in females carrying eggs in stage II, the number of eggs varied from 240 to 1822 with mean of $845.57 \pm 712.80$ eggs. Finally, in females carrying late eggs (stage III), fecundity varied from 375 to 949 eggs, with mean of $701.66 \pm 295.10$ eggs per female. An ANCOVA was conducted, but no statistically significant differences were detected between egg stages (I, II and III) on fecundity ( $\mathrm{F}=1.05$, d.f. $2, \mathrm{P}=0.37)$. In contrast, the CL significantly affected fecundity, showing large females carried more eggs than small ones $(\mathrm{F}=37.57$, d.f. $1, \mathrm{P}<0.001)$. The interaction term of ANCOVA was also significant $(\mathrm{F}=11.89$, d.f. $1, \mathrm{P}=0.003)$. This indicates that females, either large or small, did not lose eggs during embryo development. The slope of the $\log -\log$ relationship between CL and fecundity did differ significantly $(\mathrm{F}=39.79 ; \mathrm{P}<0.001)$. This indicates that fecundity did increase linearly with shrimp body size (Figure 3). 

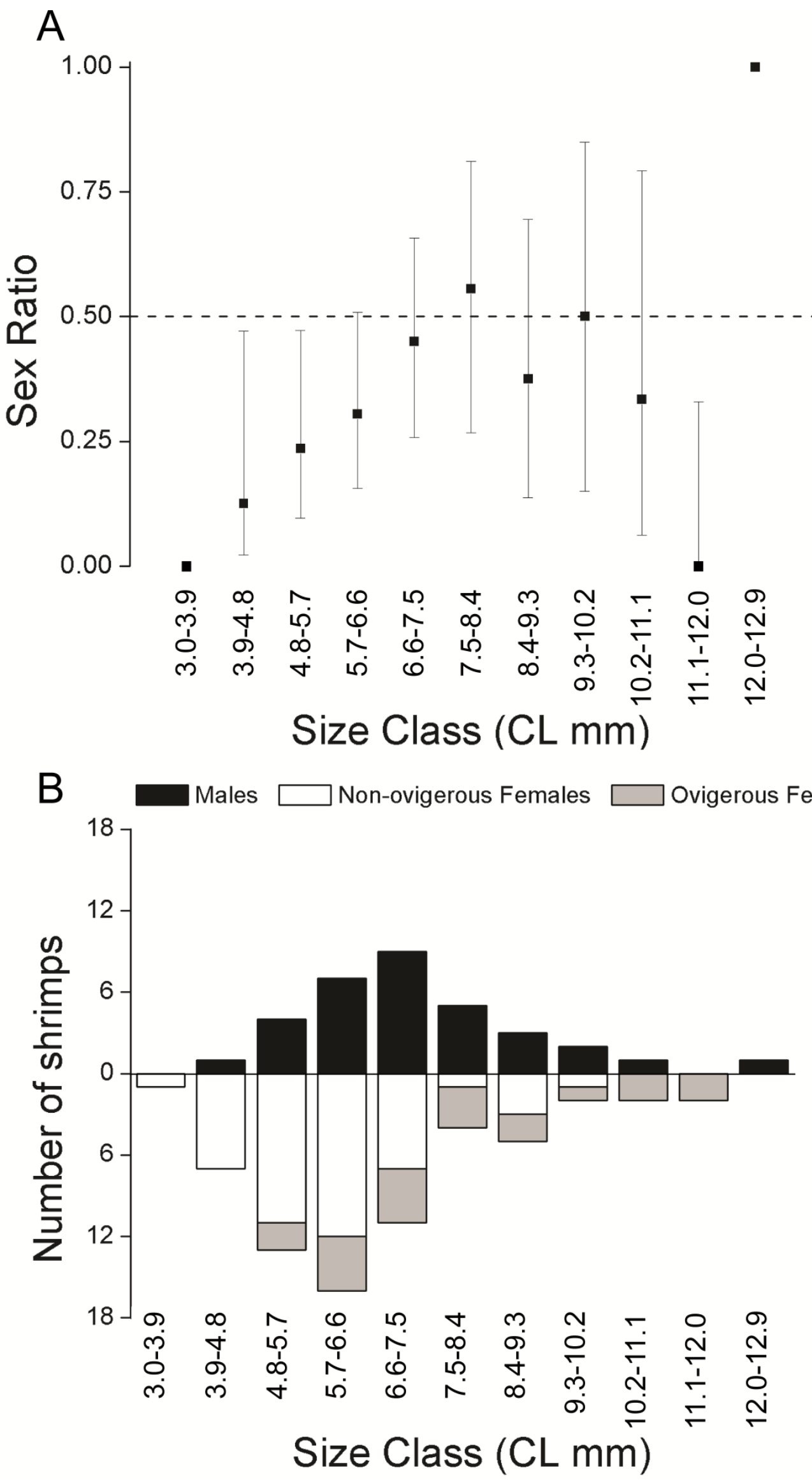

Figure 2. Upogebia omissa Gomes Corrêa, 1968: A. Sex ratio (estimate \pm SE) by size class (CL mm); B. Size frequency distribution of body size (CL $\mathrm{mm}$ ). 
Stage I $\square$ Stage II $\mathbf{a}$ Stage III

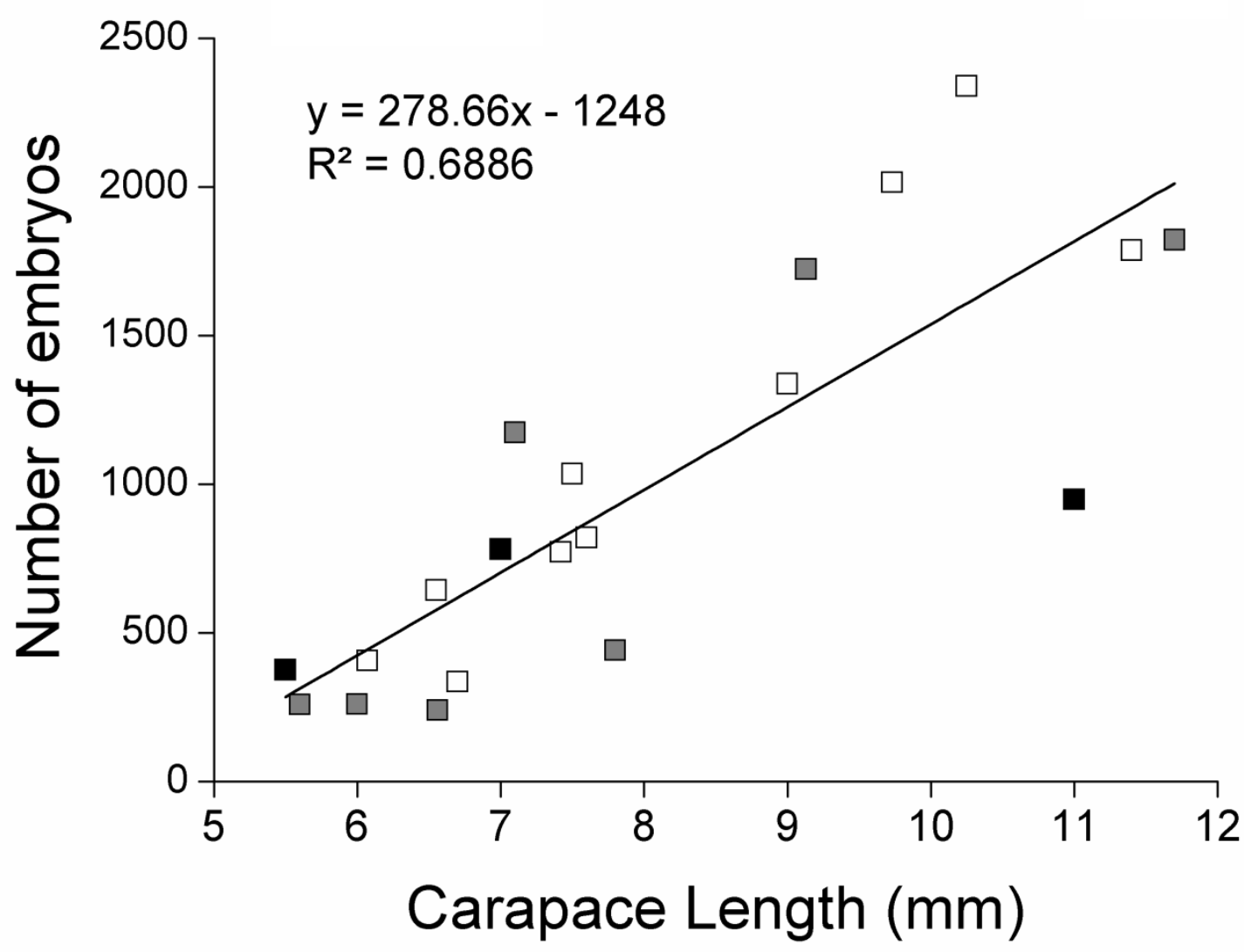

Figure 3. Relationship between the number of embryos and carapace length (CL) of Upogebia omissa Gomes Corrêa, 1968, in Sergipe, Brazil.

\section{Discussion}

The present study is the first regarding the population structure of Upogebia omissa in the Brazilian coast, allowing future comparisons, once the obtained results provides new and relevant information about this population. The sex ratio was skewed towards females, according to Wenner (1972), a deviation from the 1:1 sex ratio is expected for adult marine crustaceans. The result matched the anomalous pattern observed by Wenner (1972), in which one sex is more predominant in the intermediate size classes (in this study, males) and the other dominates at both extremities of size classes (in this study, females), an evidence of the differential growth of males and females.

The sex ratio in mud shrimps such as the Gebiidea infraorder have a general pattern of 1:1, for the overall population, although, variations can occur in some species (Hill 1977; Hanekon \& Erasmus 1989; Rotherham \& West 2009; Botter-Carvalho et al. 2015). However variations are commonly found with a female dominance (Tunberg 1986; Hanekon \& Baird 1992; Selin 2014; Botter-Carvalho et al. 2015). This pattern is more related to the competition among males for females, associated to the aggressive intraspecific behavior in the Upogebiidae family (Coelho et al. 2000; Jugovic et al. 2017). A sex-specific mortality can occur (Felder \& Lovett 1989), with males suffering higher mortality than females, when predation risk is higher for males searching for receptive females (Felder \& Lovett 1989; Dumbauld et al. 1996; BotterCarvalho et al. 2015).

The body size structure found for the population of Upogebia omissa demonstrates that males and females have a different size variation, indicating a sexual dimorphism, as males smaller than females. Similar patterns of dimorphism are found in studies with other species of the genus Upogebia, as in Upogebia stellata (Montagu, 1808) (Dworschak 1988; Pinn et al. 2001). 
In this case, females allocate most of their energy to somatic growth, resulting in larger body sizes, which allow them to incubate a larger number of eggs during their reproductive period (Pandian 2016). In addition, this increase on the body size also contribute to a better accommodation of the ovary and egg carrying in shrimps for the Gebiidea and Axiidea infraorders (formerly belonging to the Thalassinidea infraorder) (Robles et al. 2009; Poore et al. 2016). Furthermore, the body size of females is positively related to its fecundity (Bauer \& Martin 1991; Pandian 2016; Moraes et al. 2017), a pattern that is corroborated by studies regarding the fecundity in species of genus Upogebia (Hill 1977; Dumbauld et al. 1996; Yamasaki et al. 2010), as well as in the results observed for $U$. omissa in the present study.

In general, the present study raised some questions to be addressed by future studies: [1] does the relationship between the differential sex ratio and the predation risk males face when searching for receptive females to mate, and correspondingly, the deviation in the sex ratio increase during the peak of the reproductive period? [2] is intraspecific hostility related to the territorialism of Upogebia omissa? These questions were raised in the present work due personal observations that some specimens of mud shrimps quickly killed others, when put together during sampling.

Finally, although the present study provides new information about Upogebia omissa, we suggest further investigation on the biology and ecology of the Upogebiidae occurring in Brazil, seen how essential these mud shrimps are to their environment and the current scarcity of studies alike. Additionally, coastal habitats are among the most impacted environments by human actions, thus, putting at risk the populations of Upogebiidae and, consequently, all fauna associated with them that depends directly or indirectly of the ecological benefits and resources provided by this crustacean.

\section{Acknowledgements}

The authors are grateful to the colleagues Y. T. Reis and C. R. P. Guimarães (University of Sergipe, Department of Biology) for the permission to use laboratory equipment and anonymous reviewers for critically reviewing the manuscript. We sincerely appreciate the research opportunity provided by the Federal University of Sergipe and to the members of the "Laboratório de Carcinologia da UFS" for the support with the logistic assistance that helped make possible this study. All sampling in this study were performed in accordance to applicable state and federal laws regarding capture of wild animals.

\section{References}

Anderson F.O. \& Kristensen E. (1991) Effects of burrowing macrofauna on organic matter decomposition in coastal marine sediments. Symposia of the Zoological Society of London, 63: 69-88.

Atkinson R.J.A. \& Taylor A.C. (1988) Physiological ecology of burrowing decapods. Symposia of the Zoological Society of London, 59: 201-226.

Bauer R.T. \& Martin J.W. (1991) Crustacean sexual biology. New York: Columbia University Press. 355 p.

Botter-Carvalho M.L., Costa L.B., Gomes L.L., Clemente C.C.C. \& Carvalho P.V.V. da C. (2015) Reproductive biology and population structure of Axianassa australis (Crustacea, Axianassidae) on a sand-mud flat in north-east Brazil. Journal of the Marine Biological Association of the United Kingdom, 95: 735-745. DOI: 10.1017/S002531541400174X

Byers J.E. \& Grabowski J.H. (2014) Soft-sediment communities (p. 227-249). In: Bertness M.D., Bruno J.F., Silliman B.R. \& Stachowicz J.J. (Eds). Marine Community Ecology and Conservation. Sunderland, Massachusetts: Sinauer Associates. 560 p.

Carvalho M.E. \& Fontes A.L. (2007) A carcinocultura no espaço litorâneo Sergipano. Revista da Fapese, 3: 87-112. 
Coelho V.R., Cooper R.A. \& Rodrigues S.A. (2000) Burrow morphology and behavior of the mud shrimp Upogebia omissa (Decapoda: Thalassinidea: Upogebiidae). Marine Ecology Progress Series, 200: 229-240. DOI: 10.3354/meps200229

Coelho P.A., Almeida A.O., Bezerra, L.E.A. \& Souza-Filho J.F. (2007) An updated checklist of decapod crustaceans (infraorders Astacidea, Thalassinidea, Polychelida, Palinura, and Anomura) from the northern and northeastern Brazilian coast. Zootaxa, 1519: 1-16. DOI: 10.11646/zootaxa.1519.1.1

D'Andrea A.F.D. \& DeWitt T.H. (2009) Geochemical ecosystem engineering by the mud shrimp Upogebia pugettensis (Crustacea: Thalassinidea) in Yaquina Bay, Oregon: Density-dependent effects on organic matter remineralization and nutrient cycling. Limnology and Oceanography, 54: 1911-1932. DOI: 10.4319/1o.2009.54.6.1911

Das S., Tseng L., Wang L. \& Hwang J. (2017) Burrow characteristics of the mud shrimp Austinogebia edulis, an ecological engineer causing sediment modification of a tidal flat. Plos One, 12: 1-17. DOI: 10.1371/journal.pone.0187647

Dumbauld B.R., Armstrong D.A. \& Feldman K.L. (1996) Life-history characteristics of two sympatric Thallassinidean shrimps, Neotropica californiensis and Upogebia pugettensis, with implications for oyster culture. Journal of Crustacean Biology, 16: 689-708.

Dumbauld B.R., Chapman J.W., Torchin M.E. \& Kuris A.M. (2010) Is the collapse of mud shrimp (Upogebia pugettensis) populations along the Pacific Coast of North America caused by outbreaks of a previously unknown bopyrid isopod parasite (Orthione griffenis)? Estuaries and Coasts, 34: 336-350. DOI: 10.1007/s12237-010-9316-z

Dworschak P.C. (1987) The biology of Upogebia pusilla (PETAGNA) (Decapoda, Thalassinidea) II Environments and zonation. P.S.Z.N.I.: Marine Ecology, 8: 337-358.

Dworschak P.C. (1988) The biology of Upogebia pusilla (PETAGNA) (Decapoda, Thalassinidea) III Growth and Production. P.S.Z.N.I.: Marine Ecology, 9: 51-77.

Dworschak P.C. (2000) Global diversity in the Thalassinidea (Decapoda). Journal of Crustacean Biology, 20: 238-245. DOI: 10.1163/1937240X-90000025

Felder D.L. \& Lovett D.L. (1989) Relative growth and sexual maturation in the estuarine ghost shrimp Callianassa louisianensis Schmitt, 1935. Journal of Crustacean Biology, 9: 540-553. DOI: $10.2307 / 1548586$

Griffis R.B. \& Suchanek T.H. (1991) A model of burrow architecture and trophic modes in thalassinidean shrimp (Decapoda: Thalassinidea). Marine Ecology Progress Series, 79: 171183. DOI: $10.3354 /$ meps079171

Hanekon N. \& Erasmus T. (1989) Determinations of the reproductive output of populations of thalassinid prawn Upogebia africana (Ortmann) in the Swartkops estuary. South African Journal of Zoology, 24: 244-250. DOI: 10.1080/02541858.1989.11448160

Hanekon N. \& Baird D. (1992) Growth, production and consumption of the thallasinid prawn Upogebia afriana (Ortmann) in the Swartkops estuary. South African Journal of Zoology, 27: 130-139. DOI: 10.1080/02541858.1992.11448273

Hill B.J. (1977) The effect of heated effluent on egg production in the estuarine prawn Upogebia africana (Ortmann). Journal of Experimental Marine Biology and Ecology, 29: 291-302. DOI: 10.1016/0022-0981(77)90072-7

Hirose L.H., Souza L.S., Silva S.L.R., Alves D.F.R. \& Negreiros-Fransozo M.L. (2015) Population structure of the red mangrove crab, Goniopsis cruentata (Decapoda: Grapsidae) under different fishery impacts: Implications for resource management. Revista de Biologia Tropical, 63: 443-457. DOI: 10.15517/rbt.v63i2.15432

Jones C.G., Lawton J.H. \& Shachak M. (1994) Organism as ecosystem engineers. Oikos, 69: 373386. DOI: $10.1007 / 978-1-4612-4018-1 \_14$

Jugovic J., Horvat E. \& Lipej L. (2017) Seasonal abundance, vertical distribution and life history traits of Mediterranean mud shrimp Upogebia pusilla (Decapoda: Gebiidea) on the Slovenian coast. Acta Adriatica, 58: 297-312. 
Kevrekidis T., Gouvis N. \& Koukouras A. (1997) Population dynamics, reproduction and growth of Upogebia pusilla (Decapoda, Thalassinidea) in the Evros Delta (North Egean Sea). Crustaceana, 70: 799-812. DOI: 10.1163/156854097X00249

Kinoshita K. \& Itani G. (2005) Interspecific differences in the burrow morphology between the sympatric mud shrimp, Austinogebia narutensis and Upogebia issaeffi (Crustacea: Thalassinidea: Upogebiidae). Journal of the Marine Biological Association of the United Kingdom, 85: 943-947. DOI: 10.1017/S0025315405011926

Kinoshita K., Itani G. \& Uchino T. (2010) Burrow morphology and associated animals of the mud shrimp Upogebia yokoyai (Crustacea: Thalassinidea: Upogebiidae). Journal of the Marine Biological Association of the United Kingdom, 90: 947-952. DOI: 10.1017/S002531541 0000214

Meadows P.S. \& Meadows A. (1991) The environmental impact of burrowing animals and animal burrows. Oxford: Clarendon Press for the Zoological Society of London. 349 p.

Melo G.A.S. (1999) Manual de identificação dos Crustacea Decapoda do litoral brasileiro: Anomura, Thalassinidea, Palinuridea e Astacidea. São Paulo: Ed.Plêiade/FAPESP. 551 p.

Moraes I.R.R., Wolf M.R., Gonçalves G.R.L. \& Castilho A.L. (2017) Fecundity and reproductive output of the caridean shrimp Periclimenes paiva associated with scyphozoan jellyfish. Invertebrate Reproduction \& Development, 61: 71-77. DOI: 10.1080/07924259.2017.1282890

Nickell L.A. \& Atkinson R.J.A. (1995) Functional morphology of burrows and trophic modes of three thalassinidean shrimp species, and a new approach to the classification of thalassinidean burrow morphology. Marine Ecology Progress Series, 128: 181-197. DOI: $10.3354 /$ meps 128181

Pandian T.J. (2016) Reproduction and development in Crustacea. New York: CRC Press, Taylor \& Francis Group. 315 p.

Pinn E.H., James R., Atkinson A. \& Rogerson A. (2001) Sexual dimorphism and intersexuality in Upogebia stellate (Crustacea: Decapoda: Thalassinidea). Journal of the Marine Biological Association of the United Kingdom, 81: 1061-1062.

Poore G.C.B. (2016) The names of the higher taxa of Crustacea Decapoda. Journal of Crustacean Biology, 36: 248-255. DOI: 10.1163/1937240X-00002415

Robles R., Tudge C.C., Dworschak P.C., Poore G.C.B. \& Felder D.L. (2009) Molecular phylogeny of the Thalassinidea based on nuclear and mithocondrial genes (p. 309-326). In: Martin J.W., Crandal K.A. \& Felder D.L. (Eds). Decapod Crustacean phylogenetics. Volume 18. Boca Raton: CRC Press. 633 p.

Rotherham D. \& West R.J. (2009) Patterns in reproductive dynamics of burrowing ghost shrimp Trypaea australiensis from small to intermediate scales. Marine Biology, 156: 1277-1287. DOI: $10.1007 / \mathrm{s} 00227-009-1169-2$

Selin N.I. (2014) Some features of the biology of the mud shrimp Upogebia issaeffi (Balls, 1913) (Decapoda: Upogebiidae) from the subtidal zone of Vostok Bay, Sea of Japan. Russian Journal of Marine Biology, 40: 24-29. DOI: 10.1134/S1063074014010088

Tunberg B. (1986) Studies on the population ecology of Upogebia deltaura (Leach) (Crustacea, Thalassinidea). Estuarine, Coastal and Shelf Science, 22: 753-765.

Wehrtmann I.S. \& Lardies M.A. (1999) Egg production of Austropandalus grayi (Decapoda, Caridea, Pandalidae) from the Magellan region, South America. Scientia Marina, 63: 325-331.

Wenner A.M. (1972) Sex ratio as a function of size in marine Crustacea. American Naturalist, 106: 321-350.

Wilde P.A.W.J. (1991) Interactions in burrowing communities and their effects on the structure of marine benthic ecosystems (p. 107-117). In: Meadows P.S. \& Meadows A. (Eds) The environmental impact of burrowing animals and animal burrows. London: Claredon Press. $349 \mathrm{p}$.

Wilson K. \& Hardy I.C.W. (2002) Statistical analysis of sex ratios: an introduction (p. 48-92). In: Hardy I.C.W. (Eds). Sex Ratios: Concepts and Research Methods. Volume 1. Cambridge: Cambridge University Press. 424 p. 
Yamasaki M., Nanri T., Taguchi S., Takada Y. \& Saigusa M. (2010) Latitudinal and local variations of the life history characteristics of the thalassinidean decapod, Upogebia yokayai: A hypothesis based on trophic conditions. Estuarine, Coastal and Shelf Science, 87: 346-356. Zar J.H. (2010) Biostatistical Analysis. $5^{0}$ edição. Upper Saddle River: Prentice-Hall. 944 p. 